\title{
Convenient and efficient method for the synthesis of phthalocyanines and metallophthalocyanines in task specific 2-hydroxyethyl ionic liquids
}

\author{
Kumar Karitkey Yadav, Poonam and Shive Murat Singh Chauhan* \\ Bioorganic research laboratory, Department of chemistry, University of Delhi, Delhi-110007 India; Fax: +91-11- \\ 27666845; E-mail: smschauhan@chemistry.du.ac.in
}

\section{Contents}

Page

1. General information

2. Synthesis and characterization of ionic liquids

3. Synthesis and characterization of metal free phthalocyanines

$10-12$

4. Synthesis and characterization of metallophthalocyanines

$12-16$

5. Synthesis of metallophthalocyanines from metal free phthalocyanines

6. References

$17-18$

7. ${ }^{1} \mathrm{H}$ NMR and Mass Spectra

$19-20$ 


\section{General}

The ${ }^{1} \mathrm{H}$ NMR spectra were recorded on Jeol $400 \mathrm{MHz}$ spectrometer using TMS as internal standard and the chemical shifts $(\delta)$ are expressed in ppm. IR spectra were recorded on a PerkinElmer Spectrum 2000 infrared spectrophotometer. UV-Visible spectra were recorded on a Perkin-Elmer Lambda 35 UV/Vis Spectrophotometer. The mass spectra (EI-MS) were recorded on a Jeol SX-102DA-6000 (6 kV, 10ma) spectrometer and ESI-MS spectra were recorded on a Micromass LCT KC 455 spectrometer (+ve mode). Phthalonitrile (4a), 4-nitrophthalonitrile (4i) and N,N'-dimethylaminoethanol (1a) were obtained from Spectrochem Pvt. Ltd. and 4methylphthalonirile (4b) was obtained from Aldrich. N,N'-dimethylaminopropanol (1b) was obtained from Alfa-Aessar. The 4-methoxyphthalonitrile (4c), 4-butyloxyphthalonitrile (4d), 4octyloxyphthalonitrile (4e), 4-dodecyloxylphthalonitrile (4f), 4-octadecyloxyphthalonitrile (4g) and 4-(p-tert-butylphenoxy)phthalonitrile (4h) are synthesized from 4-nitrophthalonitrile by following the literature procedures. Ionic liquids 2-3 were prepared by minor modifications of the literature procedure. All reactions were carried out under $\mathrm{N}_{2}$ atmosphere except where mentioned. All other solvents and reagents were used as received. All phthalocyanines are known compounds and their analytical data were identical to those reported in different literature.

\section{Synthesis of ionic liquids}

The task specific ionic liquids were synthesized by slighty modifying the literature procedures. All ionic liquids are known compounds and their purities were confirmed by comparison with literatures. The literatures are cited in the manuscript.

\section{Butyl(2-hydroxyethyl)dimethylammonium bromide [bhyeda][Br] (2a) ${ }^{1}$}


Freshly distilled 2-dimethylaminoethanol $(4.42 \mathrm{~g}, 0.0496 \mathrm{~mol})$ in $25 \mathrm{~mL}$ benzene was placed in a $250 \mathrm{~mL}$ two necked round bottom flask equipped with a dropping funnel and reflux condenser. The flask was putted in an ice bath. Under vigorous stirring with a magnetic stirring bar solution of n-butyl bromide $(0.0496 \mathrm{~mol})$ in $25 \mathrm{~mL}$ benzene was added drop wise $\left(\right.$ at $\left.0^{\circ} \mathrm{C}\right)$ in about 45 minute. The reaction mixture was refluxed for $16 \mathrm{~h}$ to obtain a viscous liquid. Benzene was removed using rotavapour and light yellow solid was obtained. The yellowish solid product was washed with diethyl ether $(3 \times 30 \mathrm{~mL})$ and dried under vacuum for $48 \mathrm{~h}$ at $80^{\circ} \mathrm{C}$ to obtain a white solid.

Yield: 95\%, IR (nujol): v ( $\left.\mathrm{cm}^{-1}\right)$ 3254, 2965, 2876, 2462, 1652, 1487, 1464, 1380, 1238, 1049, 920, 754. ${ }^{1} \mathrm{H}$ NMR (400 MHz, $\mathrm{CDCl}_{3}$ ) ): 5.0(brs, $\left.1 \mathrm{H}\right), 4.10(\mathrm{t}, 2 \mathrm{H}), 3.73(\mathrm{t}, 2 \mathrm{H}), 3.55(\mathrm{t}, 2 \mathrm{H})$, 3.35(s, 6H), 1.73(m, 2H), 1.38-1.43(m, 2H), 0.97(t,3H). ${ }^{13} \mathrm{C}\left(400 \mathrm{MHz}, \mathrm{CDCl}_{3} \delta\right): 65.86\left(\mathrm{CH}_{2}\right)$, 65.64( $\left(\mathrm{CH}_{2}\right), 55.88\left(\mathrm{CH}_{2}\right), 52.17\left(\mathrm{CH}_{3}\right), 24.71\left(\mathrm{CH}_{2}\right), 19.61\left(\mathrm{CH}_{2}\right), 13.69\left(\mathrm{CH}_{3}\right)$.

\section{Butyl(2-hydroxyethyl)dimethylammonium hydroxide [bhyeda][OH] (2b) ${ }^{1}$}

To a solution of [bhyeda][Br] $(9 \mathrm{~g}, 40 \mathrm{mmol})(2 \mathrm{a})$ in dry methylene chloride $(20 \mathrm{~mL})$, powdered potassium hydroxide $(2.3 \mathrm{~g}, 40 \mathrm{mmol})$ was added and the reaction mixture was stirred vigorously at room temperature for $24 \mathrm{~h}$. The precipitated $\mathrm{KBr}$ was filtered off, and the filtrate was evaporated to leave the crude [bhyeda][OH] as a viscous liquid that was washed with diethyl ether $(3 \times 20 \mathrm{~mL})$ and dried at $90^{\circ} \mathrm{C}$ for $10 \mathrm{~h}$ to prepare the pure colorless ionic liquid for use.

Yield: 96\%, IR (nujol): v $\left(\mathrm{cm}^{-1}\right)$ 3435, 3247, 1486, 1047, 1027, 991, 959, 918.; ${ }^{1} \mathrm{H}$ NMR (400 $\left.\mathrm{MHz}, \mathrm{D}_{2} \mathrm{O}, \delta\right): 4.1(\mathrm{t}, 2 \mathrm{H}), 3.65(\mathrm{t}, 4 \mathrm{H}), 3.50(\mathrm{t}, 2 \mathrm{H}), 3.30(\mathrm{~s}, 6 \mathrm{H}), 1.76(\mathrm{~m}, 2 \mathrm{H}), 1.34(\mathrm{~m}, 2 \mathrm{H}), 0.93(\mathrm{t}$, $3 \mathrm{H})$.

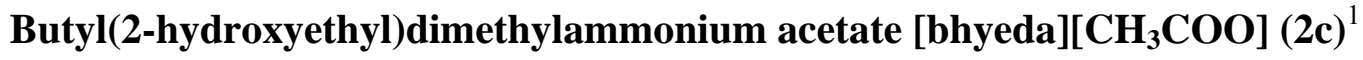


To a solution of [bhyeda][Br] $(4.87 \mathrm{~g}, 0.0215 \mathrm{~mol})$ in dry acetonitrile $(20 \mathrm{~mL})$, powdered ammonium acetate $(1.66 \mathrm{~g}, 0.0215 \mathrm{~mol})$ was added and the reaction mixture was stirred vigorously at room temperature for $36 \mathrm{~h}$. The precipitated $\mathrm{NH}_{4} \mathrm{Br}$ was filtered off, and the filtrate was evaporated to leave the crude [bhyeda] $\left[\mathrm{CH}_{3} \mathrm{COO}\right]$ as a viscous solid that was washed with diethyl ether $(3 \times 20 \mathrm{~mL})$ and dried at $90^{\circ} \mathrm{C}$ for $10 \mathrm{~h}$ to prepare the pure colorless ionic liquid for use.

Yield: 93\%, IR (nujol): v $\left(\mathrm{cm}^{-1}\right)$ 3253, 3013, 2965, 2876, 2362, 2084, 1718, 1653, 1487, 1380, 1238, 1049, 920, 753. ${ }^{1} \mathrm{H}$ NMR (400 MHz, $\mathrm{CDCl}_{3}, \delta$ ): 5.01(brs, 1H), 4.11(t, 2H), 3.73(t, 2H), 3.54(t, 2H), 3.35(s, 6H), 2.05(s, 3H), 1.69-1.77(m, 2H), 1.36-1.45(m, 2H), 0.97(t, 3H).

\section{(2-hydroxyethyl)dimethylammonium octanoate [hyeda] $\left[\mathrm{C}_{7} \mathrm{H}_{15} \mathrm{COO}\right](2 \mathrm{~d})^{1}$}

Distilled 2-dimethylaminoethanol (4.42g, 0.0496mol) was placed in a $100 \mathrm{ml}$ two necked round bottom flask equipped with a dropping funnel and reflux condenser. The flask was putted in an ice bath. Under vigorous stirring with a magnetic stirring bar octanoic acid $(5 \mathrm{mmol})$ was added drop wise $\left(\right.$ at $\left.0^{\circ} \mathrm{C}\right)$ in about 15 minute. The reaction mixture was refluxed for $24 \mathrm{~h}$ to obtain a viscous liquid. The oily-viscous liquid was washed with acetone $(3 \times 30 \mathrm{~mL})$ and dried under vacuum for $24 \mathrm{~h}$ at $80^{\circ} \mathrm{C}$ to obtain a colorless viscous ionic liquid.

Yield: 93\%, IR (nujol): v $\left(\mathrm{cm}^{-1}\right)$ 3393, 2925, 2856, 2728, 1736, 1557, 1460, 1414, 1304, 1169, 1081, 992, 923.; ${ }^{1} \mathrm{H}$ NMR (400 MHz, $\mathrm{D}_{2} \mathrm{O}, \delta$ ): 4.8(t, 2H), 3.45(t, 4H),3.25(brs, $\left.1 \mathrm{H}\right), 2.88(\mathrm{~s}, 6 \mathrm{H})$, $1.2-1.6(\mathrm{~m}, 12 \mathrm{H}), 0.68(\mathrm{t}, 3 \mathrm{H})$.

\section{Triethylammonium octanoate (2e) $)^{2}$}


Triethylamine $(0.50 \mathrm{~g}, 5 \mathrm{mmol})$ was placed in a $100 \mathrm{ml}$ round bottom flask equipped with a dropping funnel. The flask was putted in an ice bath. Under vigorous stirring with a magnetic stirring bar octanoic acid $(5 \mathrm{mmol})$ was added drop wise $\left(\right.$ at $\left.0^{\circ} \mathrm{C}\right)$ in about 15 minute. The reaction mixture was refluxed for $24 \mathrm{~h}$ to obtain a viscous liquid. The oily-viscous liquid was washed with acetone $(3 \times 30 \mathrm{~mL})$ and dried under vacuum for $48 \mathrm{~h}$ at $80^{\circ} \mathrm{C}$ to obtain a colorless viscous ionic liquid.

Yield: 91\%, IR (nujol): v $\left(\mathrm{cm}^{-1}\right)$ 3422, 2956, 2857, 2649, 2510, 1717, 1560, 1401, 1267, 1106, 1034, 838. ${ }^{1} \mathrm{H}$ NMR (400 MHz, $\left.\mathrm{D}_{2} \mathrm{O}, \delta\right): 3.2(\mathrm{q}, 6 \mathrm{H}), 3.14(\mathrm{brs}, 1 \mathrm{H}), 2.3(\mathrm{t}, 9 \mathrm{H}), 1.2-1.5(\mathrm{~m}, 12 \mathrm{H})$, $0.72(\mathrm{t}, 3 \mathrm{H})$.

\section{2-Hydroxyethyldimethylammonium acetate (2f)}

Distilled 2-dimethylaminoethanol (4.43g, $0.0498 \mathrm{~mol})$ was placed in a $100 \mathrm{~mL}$ round bottom flask equiped with a dropping funnel. The flask was putted in an ice bath. Under vigorous stirring with a magnetic stirring bar acetic acid $(0.0498 \mathrm{~mol})$ was added drop wise $\left(\right.$ at $\left.0^{\circ} \mathrm{C}\right)$ in about 45 minute. At room temperature stirring was continued for $24 \mathrm{~h}$ to obtain a viscous clear liquid. The oily-viscous liquid was washed with diethyl ether $(3 \times 30 \mathrm{~mL})$ and dried under vacuum for $48 \mathrm{~h}$ at $80^{\circ} \mathrm{C}$ to obtain a colorless viscous ionic liquid.

Yield: 96\%, IR (nujol): v (cm $\left.{ }^{-1}\right)$ 3392, 2738, 1641, 1568, 1409, 1342, 1173, 1081, 1016, 924, 882; ${ }^{1} \mathrm{H}$ NMR (400 MHz, $\left.\mathrm{D}_{2} \mathrm{O}, \delta\right): 3.70(\mathrm{t}, 2 \mathrm{H}), 3.15(\mathrm{brs}, 1 \mathrm{H}), 3.09(\mathrm{t}, 2 \mathrm{H}), 2.73(\mathrm{~s}, 6 \mathrm{H}), 1.73(\mathrm{~s}$, $3 \mathrm{H})$.

\section{2-Hydroxyethylammonium formate $(2 \mathrm{~g})^{3}$}


Distilled 2-aminoethanol $(20.24 \mathrm{~g}, 0.3313 \mathrm{~mol})$ was placed in a $250 \mathrm{~mL}$ round bottom flask equipped with a dropping funnel. The flask was mounted in an ice bath. Under vigorous stirring with a magnetic stirring bar formic acid $(0.3313 \mathrm{~mol})$ was added drop wise $\left(\right.$ at $\left.0^{\circ} \mathrm{C}\right)$ to the flask in about 30 minute. At room temperature stirring was continued for $24 \mathrm{~h}$ to obtain a viscous clear liquid. The oily-viscous liquid was washed with diethyl ether $(3 \times 30 \mathrm{~mL})$ and dried under vacuum for $24 \mathrm{~h}$ at $80^{\circ} \mathrm{C}$ to obtain a colorless viscous liquid.

Yield: 95\%, IR (nujol): v $\left(\mathrm{cm}^{-1}\right)$ 3367, 2946, 2889, 1668, 1542, 1389, 1252, 1069, 753; ${ }^{1} \mathrm{H}$ NMR (400 MHz, $\left.\mathrm{D}_{2} \mathrm{O}, \delta\right): 8.1(\mathrm{~s}, 1 \mathrm{H}), 4.03(\mathrm{brs}, 3 \mathrm{H}), 3.41(\mathrm{t}, 2 \mathrm{H}), 3.12(\mathrm{t}, 2 \mathrm{H})$.

\section{2-Hydroxyethylammonium methansulfonate (2h) ${ }^{3}$}

Distilled 2-aminoethanol $(9.40 \mathrm{~g}, 0.154 \mathrm{~mol})$ was placed in a $250 \mathrm{ml}$ round bottom flask equipped with a dropping funnel. The flask was mounted in an ice bath. Under vigorous stirring with a magnetic stirring bar methane sulfonic acid $(0.154 \mathrm{~mol})$ was added drop wise $\left(\right.$ at $\left.0^{\circ} \mathrm{C}\right)$ to the flask in about 45 minute. At room temperature stirring was continued for $24 \mathrm{~h}$ to obtain a viscous clear liquid. The oily-viscous liquid was washed with diethyl ether $(3 \times 30 \mathrm{~mL})$ and dried under vacuum for $24 \mathrm{~h}$ at $80^{\circ} \mathrm{C}$ to obtain a colorless viscous ionic liquid.

Yield: 94\%, IR (nujol): v $\left(\mathrm{cm}^{-1}\right)$ 3434, 2362, 2093, 1632, 1383, 1350, 1191, 1049, 784; ${ }^{1} \mathrm{H}$ NMR (400 MHz, $\left.\mathrm{D}_{2} \mathrm{O}, \delta\right): 5.33($ brs, $3 \mathrm{H}), 3.69(\mathrm{t}, 2 \mathrm{H}), 3.01(\mathrm{t}, 2 \mathrm{H}), 2.68(\mathrm{~s}, 3 \mathrm{H})$.

\section{2-Hydroxyethylammonium acetate $(2 \mathbf{i})^{3}$}

Distilled 2-aminoethanol $(20.24 \mathrm{~g}, 0.3313 \mathrm{~mol})$ was placed in a $250 \mathrm{~mL}$ round bottom flask equipped with a dropping funnel. The flask was mounted in an ice bath. Under vigorous stirring with a magnetic stirring bar acetic acid $(0.3313 \mathrm{~mol})$ was added drop wise $\left(\right.$ at $\left.0^{\circ} \mathrm{C}\right)$ to the flask in 
about 30 minute. At room temperature stirring was continued for $24 \mathrm{~h}$ to obtain a viscous clear liquid. The oily-viscous liquid was washed with diethyl ether $(3 \times 30 \mathrm{~mL})$ and dried under vacuum for $24 \mathrm{~h}$ at $80^{\circ} \mathrm{C}$ to obtain a colorless viscous ionic liquid.

Yield: 93\%, IR (nujol): v $\left(\mathrm{cm}^{-1}\right)$ 3392, 1640, 1557, 1410, 1343, 1071, 1018, 925, 840.; ${ }^{1} \mathrm{H}$ NMR (400 MHz, $\left.\mathrm{D}_{2} \mathrm{O}, \delta\right): 5.26$ (brs, 3H), $3.61(\mathrm{t}, 2 \mathrm{H}), 2.93(\mathrm{t}, 2 \mathrm{H}), 1.71(\mathrm{~s}, 3 \mathrm{H})$.

\section{Butyl(3-hydroxypropyl)dimethylammonium acetate [bhypda][CH $\mathrm{CH}_{3} \mathrm{COO}$ (2j) ${ }^{3}$}

Solution of distilled 3-dimethylaminopropanol (4.42g, $0.0429 \mathrm{~mol})$ in $25 \mathrm{~mL}$ benzene was placed in a $250 \mathrm{~mL}$ two necked round bottom flask equipped with a dropping funnel and reflux condenser. The flask was putted in an ice bath. Under vigorous stirring with a magnetic stirring bar solution of n-butyl bromide $(0.0429 \mathrm{~mol})$ in $25 \mathrm{~mL}$ benzene was added drop wise (at $0^{\circ} \mathrm{C}$ ) in about 45 minute. The reaction mixture was refluxed for $16 \mathrm{~h}$ to obtain a viscous liquid. Benzene was removed using rotavapour and light yellow solid was obtained. The yellowish solid product was washed with diethyl ether $(3 \times 30 \mathrm{~mL})$ and dried under vacuum for $48 \mathrm{~h}$ at $80^{\circ} \mathrm{C}$ to obtain a white solid.

To a solution of [bhypda][Br] $(4.87 \mathrm{~g}, 0.0204 \mathrm{~mol})$ in dry acetonitrile $(20 \mathrm{~mL})$, powdered ammonium acetate $(2.96 \mathrm{~g}, 0.0306 \mathrm{~mol})$ was added and the reaction mixture was stirred vigorously at room temperature for $36 \mathrm{~h}$. The precipitated $\mathrm{NH}_{4} \mathrm{Br}$ was filtered off, and the filtrate was evaporated to leave the crude [bhypda] $\left[\mathrm{CH}_{3} \mathrm{COO}\right]$ as a viscous solid that was washed with diethyl ether $(3 \times 20 \mathrm{~mL})$ and dried at $90^{\circ} \mathrm{C}$ for $10 \mathrm{~h}$ to prepare the pure colorless ionic liquid for use.

Yield: 82\%, IR (nujol): v $\left(\mathrm{cm}^{-1}\right) 3254,3011,2963,2878,2362,2086,1716,1654,1485,1382$, 1237, 1045, 924, 753.; ${ }^{1} \mathrm{H}$ NMR (400 MHz, $\mathrm{D}_{2} \mathrm{O}, \delta$ ): 4.78(brs, 1H), 3.76(t, 2H), 3.56(t, 2H), 
3.54(t, 2H), 3.30(s, 6H), 2.05(s, 3H), 1.86-1.94(m, 2H), 1.69-1.77(m, 2H), 1.36-1.45(m, 2H), $0.97(\mathrm{t}, 3 \mathrm{H})$.

\section{1-Butyl-3-methylimidazolium bromide [bmim][Br] (3a) ${ }^{4}$}

Freshly distilled 1-methylimidazole $(8.21 \mathrm{~g}, 0.1 \mathrm{~mol})$ and n-butylbromide $(13.7 \mathrm{~g}, 0.1 \mathrm{~mol})$ were combined in $100 \mathrm{~mL}$ round bottom flask equiped with a reflux condenser. The reaction mixture was heated to reflux $\left(90^{\circ} \mathrm{C}\right)$ under $\mathrm{N}_{2}$ atmosphere for $24 \mathrm{~h}$. The product was washed with ethyl acetate $(3 \times 30 \mathrm{~mL})$ to remove starting material. The residual ethyl acetate was removed from product under vacuum pressure. The yellow solid was dissolved in water $(50 \mathrm{~mL})$ and decolorizing charcoal $(2 \mathrm{~g})$ was added. This solution was heated at $70^{\circ} \mathrm{C}$ for $24 \mathrm{~h}$, cooled and filtered. The water was removed using rotavapor. The resulting solid was heated under high vacuum for $48 \mathrm{~h}$ at $70^{\circ} \mathrm{C}$. The product was obtained as a white solid.

Yield: 94\%, IR (nujol): $v\left(\mathrm{~cm}^{-1}\right)$ 3440, 3142, 3072, 2960, 1552, 1488, 800, 768, 624; ${ }^{1} \mathrm{H}$ NMR $\left(400 \mathrm{MHz}, \mathrm{CDCl}_{3} \delta\right):$ 9.12(s, $\left.1 \mathrm{H}\right), 7.53(\mathrm{~d}, 1 \mathrm{H}), 7.46(\mathrm{~d}, 1 \mathrm{H}), 4.13(\mathrm{t}, 2 \mathrm{H}), 3.72(\mathrm{~s}, 3 \mathrm{H}), 1.83(\mathrm{~m}$, $2 \mathrm{H}), 1.36(\mathrm{~m}, 2 \mathrm{H}), 0.92(\mathrm{t}, 3 \mathrm{H})$.

\section{1-Butyl-3-methylimidazolium tetrafluoroborate $[\mathrm{bmim}]\left[\mathrm{BF}_{4}\right](3 \mathbf{b})^{4}$}

To a solution of $[\mathrm{bmim}]\left[\mathrm{BF}_{4}\right](5.47 \mathrm{~g}, 0.25 \mathrm{~mol})$ in dry acetone $(50 \mathrm{~mL})$, sodium tetrafluoroborate (5.0g) was added and reaction mixture was stirred vigorously at room temperature for $24 \mathrm{~h}$. The precipitated solid sodium bromide was filtered off, and the filtrate was evaporated to leave the crude $[\mathrm{bmim}]\left[\mathrm{BF}_{4}\right]$ as a viscous liquid. It was washed with diethyl ether $(3 \times 30 \mathrm{~mL})$ and dried at $90^{\circ} \mathrm{C}$ for $10 \mathrm{~h}$ to afford the pure colorless ionic liquid 
Yield: 95\%, IR (nujol): v $\left(\mathrm{cm}^{-1}\right)$ 3150, 3094, 2874, 1631, 1571, 1464, 1382, 1168, 753. ${ }^{1} \mathrm{H}$ NMR $\left(400 \mathrm{MHz}, \mathrm{CDCl}_{3}, \delta\right): 8.98(\mathrm{~s}, 1 \mathrm{H}), 7.49(\mathrm{~s}, 2 \mathrm{H}), 4.21(\mathrm{t}, 2 \mathrm{H}), 4.01(\mathrm{~s}, 3 \mathrm{H}), 1.85(\mathrm{~m}, 2 \mathrm{H}), 1.35(\mathrm{~m}$, 2H), $0.91(\mathrm{t}, 3 \mathrm{H})$.

\section{1-Butyl-3-methylimidazolium hydroxide [bmim][OH] $(3 \mathrm{c})^{5}$}

To a solution of $[\mathrm{bmim}][\mathrm{Br}](2 \mathrm{~g}, 9.12 \mathrm{mmol})$ in dry methylene chloride $(20 \mathrm{~mL})$, powdered potassium hydroxide $(9.12 \mathrm{mmol})$ was added and the reaction mixture was stirred vigorously at room temperature for $24 \mathrm{~h}$. The precipitated potassium bromide was filtered off, and the filtrate was evaporated to leave the crude $[\mathrm{bmim}][\mathrm{OH}]$ as a viscous liquid. It was washed with diethyl ether $(3 \times 30 \mathrm{~mL})$ and dried at $90^{\circ} \mathrm{C}$ for $10 \mathrm{~h}$ to afford the pure colorless ionic liquid.

Yield: 95\%, ${ }^{1} \mathrm{H}$ NMR $\left(400 \mathrm{MHz}, \mathrm{CDCl}_{3} \delta\right): 9.74(\mathrm{~s}, 1 \mathrm{H}), 7.51(\mathrm{~d}, 1 \mathrm{H}), 7.39(\mathrm{~d}, 1 \mathrm{H}), 4.13(\mathrm{t}, 2 \mathrm{H})$, $3.89(\mathrm{~s}, 3 \mathrm{H}), 3.24$ (brs, 1H), $1.68(\mathrm{~m}, 2 \mathrm{H}), 1.16(\mathrm{~m}, 2 \mathrm{H}), 0.72(\mathrm{t}, 3 \mathrm{H})$.

\section{1-Butyl-3-methylimidazolium acetate [bmim] $\left.\mathrm{CH}_{3} \mathrm{COO}\right](3 \mathrm{~d})^{6}$}

To a solution of [bmim] [Cl] $(0.700 \mathrm{~g}, 4 \mathrm{mmol})$ in water $(10 \mathrm{~mL}), \mathrm{CH}_{3} \mathrm{COOAg}(0.67 \mathrm{~g}, 4 \mathrm{mmol})$ was added and reaction mixture was stirred at room temperature for $4 \mathrm{~h}$. The suspension was filtered to remove silver chloride. The water was removed in vacuum to afford $0.69 \mathrm{~g}(85 \%)$ of a colorless oily ionic liquid.

Yield: 85\%, IR (nujol): $v\left(\mathrm{~cm}^{-1}\right) 3147,2875,2067,1630,1573,1339,1169,1022,849,755 . ;{ }^{1} \mathrm{H}$ NMR (400 MHz, $\left.\mathrm{CDCl}_{3}, \delta\right): 9.95(\mathrm{~s}, 1 \mathrm{H}), 7.53(\mathrm{~d}, 1 \mathrm{H}), 7.42(\mathrm{~d}, 1 \mathrm{H}), 4.18(\mathrm{t}, 2 \mathrm{H}), 3.94(\mathrm{~s}, 3 \mathrm{H})$, 2.80(s, 3H), 1.72(m, 2H), 1.20(m, 2H), 0.78(t, 3H).

1-(2'-hydroxyethyl)-3methylimidazolium acetate [HOEMIM][CH $\left.\mathrm{CHOO}_{3} \mathrm{COe}\right)^{7}$ 
To a solution of [HOEMIM] $\mathrm{Br}](1 \mathrm{~g}, 4.82 \mathrm{mmol})$ in dry acetonitrile $(20 \mathrm{~mL})$, powdered ammonium acetate $(0.3722 \mathrm{~g}, 4.82 \mathrm{mmol})$ was added and the reaction mixture was stirred vigorously at room temperature for $36 \mathrm{~h}$. The precipitated $\mathrm{NH}_{4} \mathrm{Br}$ was filtered off, and the filtrate was evaporated to leave the crude $[\mathrm{HOEMIM}]\left[\mathrm{CH}_{3} \mathrm{COO}\right]$ as a viscous liquid that was washed with diethyl ether $(3 \times 20 \mathrm{~mL})$ and dried at $90^{\circ} \mathrm{C}$ for $10 \mathrm{~h}$ to prepare the pure colorless ionic liquid for use.

Yield: 96\%, ${ }^{1} \mathrm{H}$ NMR (400 MHz, $\left.\mathrm{D}_{2} \mathrm{O}, \delta\right): 8.64(\mathrm{~s}, 1 \mathrm{H}), 7.39(\mathrm{~d}, 1 \mathrm{H}), 7.34(\mathrm{~d}, 1 \mathrm{H}), 4.19(\mathrm{t}, 2 \mathrm{H})$, 3.80(t, 2H), 3.78(s, 3H), 2.62(s, 3H).

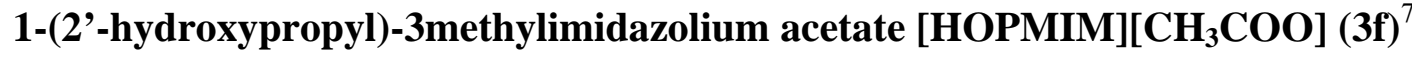

To a solution of [HOPMIM] $\mathrm{Br}](3 \mathrm{~g}, 0.0169 \mathrm{~mol})$ in dry acetonitrile $(20 \mathrm{~mL})$, powdered ammonium acetate $(1.309 \mathrm{~g}, 0.0169 \mathrm{~mol})$ was added and the reaction mixture was stirred vigorously at room temperature for $36 \mathrm{~h}$. The precipitated $\mathrm{NH}_{4} \mathrm{Br}$ was filtered off, and the filtrate was evaporated to leave the crude $[\mathrm{HOPMIM}]\left[\mathrm{CH}_{3} \mathrm{COO}\right]$ as a viscous liquid that was washed with diethyl ether $(3 \times 20 \mathrm{~mL})$ and dried at $90^{\circ} \mathrm{C}$ for $10 \mathrm{~h}$ to prepare the pure colorless ionic liquid for use.

Yield: 94\%, ${ }^{1} \mathrm{H}$ NMR (400 MHz, $\mathrm{D}_{2} \mathrm{O} \delta$ ): 10.14(s, 1H), 7.34(d, 1H), 7.22(d, 1H), 3.77 (s, 3H), 3. $72(\mathrm{t}, 2 \mathrm{H}), 2.60(\mathrm{~s}, 3 \mathrm{H}), 1.78(\mathrm{t}, 2 \mathrm{H}), 1.32(\mathrm{t}, 2 \mathrm{H})$.

\section{Synthesis of metal free phthalocyanines; Method A}

A mixture of phthalonitrile (4a-g, $200 \mathrm{mg}$ ) and functional ionic liquid 2c (1 equivalent) was stirred at $100^{\circ} \mathrm{C}$ under a nitrogen atmosphere for the appropriate time (Table 4). The progress of the reaction was monitored by TLC and UV-Visible spectroscopic analysis. When reaction was 
completed, the mixture was cooled to room temperature, and distilled water $(50 \mathrm{~mL})$ was added to dissolve the functional ionic liquid. The blue-green solid mass was filtered and the aqueous filtrate was evaporated under reduced pressure to recover the ionic liquid pure enough for further use. The solid mass was further washed thoroughly with $\mathrm{H}_{2} \mathrm{O}-\mathrm{MeOH}(1: 1,100 \mathrm{~mL})$ to remove the impurities and phthalocyanines are obtained in pure form. All of the phthalocyanines are known compounds and their purities were confirmed by comparison with literature.

Phthalocyanine (5a) $\mathrm{C}_{32} \mathbf{H}_{18} \mathbf{N}_{8}^{8,9}$

IR (nujol): 3410, 3396, 1608, 1499, 1320, 1276, 1157, 1118, 1093, 1004, 873, 735, $714 \mathrm{~cm}^{-1}$.

UV-Vis (DMF): $\lambda_{\max }\left(\mathrm{A}_{\max }\right) 276.76(2.45), 603.82(0.06), 639.39(0.088), 656.39(0.18), 693.29$

$\mathrm{nm}$ (0.19). Analysis: calcd for $\mathrm{C}_{32} \mathrm{H}_{18} \mathrm{~N}_{8} \mathrm{C}, 74.70 ; \mathrm{H}, 3.53$; N, 21.78; Found: C, 74.96; H, 3.61; $\mathrm{N}$, 22.08. MS (ESI): $\mathrm{m} / \mathrm{z}$ calcd for $\mathrm{C}_{32} \mathrm{H}_{18} \mathrm{~N}_{8}$ : 514.54; found: $515.62\left[\mathrm{M}+\mathrm{H}^{+}\right]$.

\section{2(3),9(10),16(17),23(24)-Tetrakis(methyl)phthalocyanine $\mathrm{C}_{36} \mathrm{H}_{26} \mathrm{~N}_{8}(\mathbf{5 b})^{10}$}

IR (nujol): 3366, 3082, 1643, 1502, 1319, 1155, $873 \mathrm{~cm}^{-1} . \mathrm{UV}-\mathrm{Vis}(\mathrm{DMF}): \lambda_{\max }\left(\mathrm{A}_{\max }\right) 332$ (0.82), 598 (0.24), 663 (1.4), $692 \mathrm{~nm}$ (1.6). Analysis: calcd for $\mathrm{C}_{36} \mathrm{H}_{26} \mathrm{~N}_{8} \mathrm{C}, 75.77 ; \mathrm{H}, 4.59$; N, 19.64; Found: C, 75.97; H, 4.86; N, 19.86.

\section{2(3),9(10),16(17),23(24)-Tetrakis(methoxy)phthalocyanine $\mathrm{C}_{36} \mathrm{H}_{26} \mathrm{~N}_{8} \mathrm{O}_{4}(5 \mathrm{c})^{8 \mathrm{a}}$}

IR (nujol): $3286,1613,1345,1242,1098,1012,821,743,721 \mathrm{~cm}^{-1} . \mathrm{UV}-\mathrm{Vis}\left(\mathrm{CHCl}_{3}\right): \lambda_{\max }$ $\left(A_{\max }\right) 288.79(0.18), 344.03(0.32), 392.04(0.16), 607.78(0.12), 642.18(0.22), 666.18(0.48)$, $702.61 \mathrm{~nm}$ (0.55). Analysis: calcd for $\mathrm{C}_{36} \mathrm{H}_{26} \mathrm{~N}_{8} \mathrm{O}_{4} \mathrm{C}, 68.13 ; \mathrm{H}, 4.13 ; \mathrm{N}, 17.66$; Found: $\mathrm{C}, 68.42$; $\mathrm{H}, 4.58 ; \mathrm{N}, 17.87$.

2(3),9(10),16(17),23(24)-Tetrakis(butoxy)phthalocyanine $\mathrm{C}_{48} \mathrm{H}_{50} \mathrm{~N}_{8} \mathrm{O}_{4}(5 \mathrm{~d})^{10}$ 
IR (neat): 3274, 3056, 2935, 1607, 1489, 1464, 1338, 1293, 1230, 1117, 1090, 1054, $745 \mathrm{~cm}^{-1}$.

UV-Vis $\left(\mathrm{CHCl}_{3}\right): \lambda_{\max }\left(\mathrm{A}_{\max }\right) 296.99$ (2.18), 306.74 (2.18), $608.16(0.06), 639$ (0.08), 689.17 (0.17), $705.23 \mathrm{~nm}$ (0.19). Analysis: calcd for $\mathrm{C}_{48} \mathrm{H}_{50} \mathrm{~N}_{8} \mathrm{O}_{4} \mathrm{C}, 71.80 ; \mathrm{H}, 6.28 ; \mathrm{N}, 13.96$; Found: $\mathrm{C}$, 71.96; H, 6.49; N, 14.21 .

\section{2(3),9(10),16(17),23(24)-Tetrakis(octoxy)phthalocyanine $\mathrm{C}_{64} \mathrm{H}_{82} \mathrm{~N}_{8} \mathrm{O}_{4}(5 e)^{8 \mathrm{a}}$}

IR (nujol): 3294, 2988, 1663, 1611, 1349, 1242, 1100, 1023, 832, $750 \mathrm{~cm}^{-1} . \mathrm{UV}-\mathrm{Vis}\left(\mathrm{CHCl}_{3}\right)$ : $\lambda_{\max }\left(\mathrm{A}_{\max }\right) 289.51(0.25), 343.93(0.44), 389.77$ (0.22), $607.81(0.17), 646.37(0.29), 668.78$ (0.69), $705.80 \mathrm{~nm}(0.81)$. Analysis: calcd for $\mathrm{C}_{64} \mathrm{H}_{82} \mathrm{~N}_{8} \mathrm{O}_{4} \mathrm{C}, 74.82 ; \mathrm{H}, 8.04 ; \mathrm{N}, 10.91$; Found: $\mathrm{C}$, 74.64; H, 8.35; N, 11.08 .

\section{2(3),9(10),16(17),23(24)-Tetrakis(dodecyloxy)phthalocyanine $\mathrm{C}_{80} \mathrm{H}_{114} \mathrm{~N}_{8} \mathrm{O}_{4}(5 f)^{8 \mathrm{a}}$}

IR (nujol): $3293,1612,1345,1244,1116,1097,1010,824,748,721 \mathrm{~cm}^{-1} . \mathrm{UV}-\mathrm{Vis}\left(\mathrm{CHCl}_{3}\right): \lambda_{\max }$ $\left(A_{\max }\right) 289.55(0.31), 343.72(0.50), 389.78(0.27), 608.10(0.20), 668.88(0.77), 705.78 \mathrm{~nm}$ (0.90). Analysis: calcd for $\mathrm{C}_{80} \mathrm{H}_{114} \mathrm{~N}_{8} \mathrm{O}_{4} \mathrm{C}, 76.76 ; \mathrm{H}, 9.18 ; \mathrm{N}, 8.95$; Found: $\mathrm{C}, 76.98 ; \mathrm{H}, 9.47 ; \mathrm{N}$, 9.32 .

\section{2(3),9(10),16(17),23(24)-Tetrakis(octadecyloxy)phthalocyanine $\mathrm{C}_{104} \mathrm{H}_{162} \mathrm{~N}_{8} \mathrm{O}_{4}(5 \mathrm{~g})^{8 \mathrm{a}}$}

IR (nujol): 3437, 2919, 2850, 1591, 1467, 1382, 1279, 1096, 1023, 854, 742, $721 \mathrm{~cm}^{-1}$. UV-Vis $\left(\mathrm{CHCl}_{3}\right): \lambda_{\max }\left(\mathrm{A}_{\max }\right) 290.28(0.65), 347.96(0.49), 421.17(0.11), 603.18(0.11), 648.36(0.24)$, $664.72(0.54), 702.41 \mathrm{~nm}(0.67)$. Analysis: calcd for $\mathrm{C}_{104} \mathrm{H}_{162} \mathrm{~N}_{8} \mathrm{O}_{4} \mathrm{C}, 78.64 ; \mathrm{H}, 10.28 ; \mathrm{N}, 7.05$; Found: C, 78.94; H, 10.57; N, 7.36.

\section{Synthesis of metallophthalocyanines; Method B}


A mixture of desired phthalonitrile (4a-i, 200mg) and corresponding metal salts $(0.25$ equivalents) were stirred at $100^{\circ} \mathrm{C}$ with functional ionic liquid 2c (1 equivalent) for the appropriate time (Table 1, 2 and 3). The progress of the reaction was monitored by TLC and UVVisible spectroscopic analysis. When reaction was completed, the mixture was cooled to room temperature, and distilled water $(50 \mathrm{~mL})$ was added to dissolve the functional ionic liquid. The blue-green solid mass was filtered and the aqueous filtrate was evaporated using reduced pressure to recover the pure ionic liquid for further use. The solid mass was further washed thoroughly with $\mathrm{H}_{2} \mathrm{O}-\mathrm{MeOH}(1: 1,100 \mathrm{~mL})$ to remove the colorless impurities and metallophthalocyanines are obtained in pure form. All of the phthalocyanines are known compounds and their purities were confirmed by UV-Visible spectroscopic analysis and further comparison with literature.

\section{Phthalocyaninatocobalt(II) $\mathrm{C}_{32} \mathrm{H}_{16} \mathrm{~N}_{8} \mathrm{Co}(6 \mathrm{6})^{8 \mathrm{c}}$}

IR (nujol): 3076, 3021, 1654, 1608, 1479, 1426, 1162, 1270, 1090, 913, 805, 764, $733 \mathrm{~cm}^{-1}$. UVVis (DMF): $\lambda_{\max }$ (log e) 282.84 (4.71), 328.11 (4.71), 602.91 (4.42), $666.4 \mathrm{~nm}$ (5.09). Analysis: calcd for $\mathrm{C}_{32} \mathrm{H}_{16} \mathrm{~N}_{8} \mathrm{Co}$ C, 67.26; H, 2.82; N, 19.61; Found: C, 67.44; H, 2.96; N, 19.92. MS (ESI): $\mathrm{m} / \mathrm{z}$ calcd for $\mathrm{C}_{32} \mathrm{H}_{16} \mathrm{~N}_{8} \mathrm{Co}$ : 571.08 ; found: $572.32\left[\mathrm{M}+\mathrm{H}^{+}\right]$.

\section{[2(3),9(10),16(17),23(24)-Tetrakis(methyl)phthalocyaninato] cobalt(II) $\mathrm{C}_{36} \mathrm{H}_{24} \mathrm{~N}_{8} \mathrm{Co}$ (6b)}

IR (nujol): 3068, 3024, 2986, 1615, 1523, 1323, 1276, 1167, 1094, 1066, 941, 817, $749 \mathrm{~cm}^{-1}$. UV-Vis (DMF): $\lambda_{\max }$ (log e) 337 (3.57), 602 (3.09), $665 \mathrm{~nm}$ (5.28). Analysis: calcd for $\mathrm{C}_{36} \mathrm{H}_{24} \mathrm{~N}_{8} \mathrm{Co}$ C, 68.90; H, 3.85; N, 17.86; Found: C, 69.21; H, 3.63; N, 17.98.

[2(3),9(10),16(17),23(24)-Tetrakis(methoxy)phthalocyaninato] cobalt(II) $\quad \mathrm{C}_{36} \mathrm{H}_{24} \mathrm{~N}_{8} \mathrm{O}_{4} \mathrm{Co}$ (6c) $)^{8 c}$ 
IR (nujol): 3189, 3066, 2942, 1619, 1489, 1460, 1295, 1237, 1111, 1053, 1021, 897, 844, 749 $\mathrm{cm}^{-1}$. UV-Vis (DMF): $\lambda_{\max }(\log$ e) 318 (3.96), 601 (2.66), $667 \mathrm{~nm}$ (5.37). Analysis: calcd for $\mathrm{C}_{36} \mathrm{H}_{24} \mathrm{~N}_{8} \mathrm{O}_{4} \mathrm{Co}$ C, 62.52; H, 3.50; N, 16.20; Found: C, 62.82; H, 3.74; N, 16.56 .

[2(3),9(10),16(17),23(24)-Tetrakis(butoxy)phthalocyaninato] cobalt(II) $\mathrm{C}_{48} \mathrm{H}_{48} \mathrm{~N}_{8} \mathrm{O}_{4} \mathrm{Co}$ (6d) ${ }^{11}$ IR (nujol): 3169, 3056, 2935, 1607, 1489, 1464, 1338, 1293, 1230, 1117, 1090, 1054, $745 \mathrm{~cm}^{-1}$. UV-Vis (DMF): $\lambda_{\max }(\log \varepsilon) 287$ (4.57), 350 (4.92), 615 (4.57), $682 \mathrm{~nm}$ (5.27). Analysis: calcd for $\mathrm{C}_{48} \mathrm{H}_{48} \mathrm{~N}_{8} \mathrm{O}_{4} \mathrm{Co}$ C, 67.05; H, 5.63; N, 13.03; Found: C, 67.33; H, 5.82; N, 13.31 .

[2(3),9(10),16(17),23(24)-Tetrakis(octoxy)phthalocyaninato] cobalt(II) $\mathrm{C}_{64} \mathrm{H}_{80} \mathrm{~N}_{8} \mathrm{O}_{4} \mathrm{Co}(6 \mathrm{e})^{8 \mathrm{c}}$ IR (nujol): 3043, 2944, 2835, 1608, 1490, 1464, 1339, 1283, 1226, 1119, 1091, 1052, $743 \mathrm{~cm}^{-1}$. UV-Vis (DMF): $\lambda_{\max }(\log \varepsilon) 287$ (4.48), 350 (4.86), 615 (4.64), $682 \mathrm{~nm}$ (5.36). Analysis: calcd for $\mathrm{C}_{64} \mathrm{H}_{80} \mathrm{~N}_{8} \mathrm{O}_{4} \mathrm{Co}$ C, 70.89; H, 7.44; N, 10.33; Found: C, 70.98; H, 7.67; N, 10.57 .

[2(3),9(10),16(17),23(24)-Tetrakis(dodecyloxy)phthalocyaninato] cobalt(II) $\mathrm{C}_{80} \mathrm{H}_{112} \mathrm{~N}_{8} \mathrm{O}_{4} \mathrm{Co}$ $(6 \mathbf{6})^{8 c}$

IR (nujol): 3037, 2972, 2912, 1606, 1482, 1454, 1336, 1233, 1124, 1082, 1042, $754 \mathrm{~cm}^{-1}$. UVVis (DMF): $\lambda_{\max }(\log \varepsilon) 285$ (4.46), 350 (4.78), 616 (4.44), $681 \mathrm{~nm}$ (5.23). Analysis: calcd for $\mathrm{C}_{80} \mathrm{H}_{112} \mathrm{~N}_{8} \mathrm{O}_{4} \mathrm{Co} C, 73.42 ; \mathrm{H}, 8.63 ; \mathrm{N}, 8.56$; Found: C, 73.78; H, 8.98; N, 8.96.

[2(3),9(10),16(17),23(24)-Tetrakis(octadecyloxy)phthalocyaninato] cobalt(II) $\mathrm{C}_{104} \mathrm{H}_{160} \mathrm{~N}_{8} \mathrm{O}_{4} \mathrm{Co}(6 \mathrm{~g})^{8 \mathrm{c}}$ 
IR (nujol): 3033, 2982, 2922, 1608, 1491, 1464, 1339, 1241, 1120, 1090, 1051, $744 \mathrm{~cm}^{-1}$. UV-

Vis (DMF): $\lambda_{\max }(\log \varepsilon) 284$ (4.47), 350 (4.72), 615 (4.34), $683 \mathrm{~nm}$ (5.03). Analysis: calcd for $\mathrm{C}_{104} \mathrm{H}_{160} \mathrm{~N}_{8} \mathrm{O}_{4}$ Co C, 75.92; H, 9.80; N, 6.81; Found: C, 76.32; H, 9.62; N, 7.13.

[2(3),9(10),16(17),23(24)-Tetrakis(4-tert-butylphenyloxy)phthalocyaninato]

cobalt(II)

$\mathrm{C}_{72} \mathrm{H}_{64} \mathrm{~N}_{8} \mathrm{O}_{4} \mathrm{Co}(6 h)^{12}$

IR (nujol): 3023, 2980, 2926, 1619, 1522, 1321, 1279, 1164, 1092, 1031, 942, 813, 748, $684 \mathrm{~cm}^{-}$

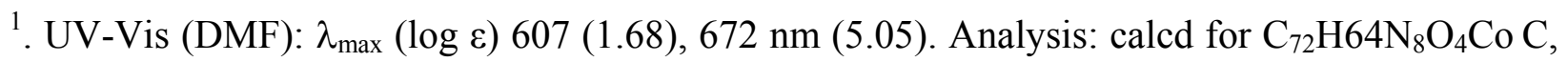
74.28; H, 5.54; N, 9.62; Found: C, 74.56; H, 5.98; N, 9.93.

\section{[2(3),9(10),16(17),23(24)-Tetrakis(nitro)phthalocyaninato]cobalt(II) $\mathrm{C}_{32} \mathrm{H}_{12} \mathrm{~N}_{12} \mathrm{O}_{8} \mathrm{Co}(6 \mathrm{i})^{8 \mathrm{c}}$}

IR (nujol): 3070, 3000, 1654, 1612, 1543, 1502, 1471, 1426, 1342, 1286, 919, 875, $777 \mathrm{~cm}^{-1}$. UV-Vis (DMF): $\lambda_{\max }(\log$ e) 274 (4.96), 606 (3.74), $667 \mathrm{~nm}$ (5.10). Analysis: calcd for $\mathrm{C}_{32} \mathrm{H}_{12} \mathrm{~N}_{12} \mathrm{O}_{8} \mathrm{Co}$ C, 51.15; H, 1.61; N, 22.37; Found: C, 51.46; H, 1.97; N, 22.62.

\section{Phthalocyaninatozinc(II) $\mathrm{C}_{32} \mathrm{H}_{16} \mathrm{~N}_{8} \mathrm{Zn}(7 \mathrm{a})^{8 \mathrm{c}}$}

IR (nujol): 3106, 3086, 1646, 1602, 1591, 1574, 1508, 1446, 1318, 1195, 1116, 1089, 1084, 906, 768, $723 \mathrm{~cm}^{-1}$. UV-Vis (DMF): $\lambda_{\max }(\log$ e) 279 (4.23), 343 (4.44), 604 (4.23), $669 \mathrm{~nm}(5.05)$. Analysis: calcd for $\mathrm{C}_{32} \mathrm{H}_{16} \mathrm{~N}_{8} \mathrm{Zn} \mathrm{C}, 66.50 ; \mathrm{H}, 2.79 ; \mathrm{N}, 19.39$; Found: C, 66.96; H, 2.61; N, 19.68. MS (ESI): m/z calcd for $\mathrm{C}_{32} \mathrm{H}_{16} \mathrm{~N}_{8} \mathrm{Zn}$ : 577.91; found: $578.96\left[\mathrm{M}+\mathrm{H}^{+}\right]$.

\section{Phthalocyaninatonickle(II) $\mathrm{C}_{32} \mathrm{H}_{16} \mathrm{~N}_{8} \mathrm{Ni}(8 \mathrm{aa})^{8 \mathrm{c}}$}

IR (nujol): 3104, 3076, 3024, 2970, 2935, 1642, 1599, 1523, 1484, 1412, 1336, 1220, 1159, $1118,1093,1006,962,857,764,732 \mathrm{~cm}^{-1}$. UV-Vis (DMF): $\lambda_{\max }(\log \varepsilon) 275$ (3.28), 637 (2.68), 
$665 \mathrm{~nm}$ (5.06). Analysis: calcd for $\mathrm{C}_{32} \mathrm{H}_{16} \mathrm{~N}_{8} \mathrm{Ni} \mathrm{C}, 67.28 ; \mathrm{H}, 2.82 ; \mathrm{N}, 19.62$; Found: C, 67.54; H, 2.98; $\mathrm{N}, 19.88$. MS (ESI): $\mathrm{m} / \mathrm{z}$ calcd for $\mathrm{C}_{32} \mathrm{H}_{16} \mathrm{~N}_{8} \mathrm{Ni}: 571.21$; found: $572.28\left[\mathrm{M}+\mathrm{H}^{+}\right]$.

\section{Phthalocyanitolead(II) $\mathrm{C}_{32} \mathrm{H}_{16} \mathrm{~N}_{8} \mathrm{~Pb}(9 \mathrm{a})^{13}$}

IR (nujol): 3098, 3049, 2925, 2855, 1668, 1590, 1509, 1474, 1332, 1290, 1208, 1110, 1074, 966, 915, 868, $727 \mathrm{~cm}^{-1}$. UV-Vis (DMF): $\lambda_{\max }(\log$ e) $333(4.16), 632(2.3), 670(4.72), 701 \mathrm{~nm}$ (5.29). Analysis: calcd for $\mathrm{C}_{32} \mathrm{H}_{16} \mathrm{~N}_{8} \mathrm{~Pb}$ C, 53.40; H, 2.24; N, 15.57; Found: C, 53.82; H, 2.44; N, 15.73 .

\section{Phthalocyaninatoiron(III) chloride $\mathrm{C}_{32} \mathrm{H}_{16} \mathrm{~N}_{8} \mathrm{FeCl}(10 \mathrm{a})^{8 \mathrm{c}}$}

IR (nujol): 3108, 3082, 2925, 1652, 1529, 1474, 1420, 1333, 1289, 1120, 1089, 1026, 908, 880, 755, $724 \mathrm{~cm}^{-1}$. UV-Vis (DMF): $\lambda_{\max }(\log$ e) 296 (4.79), 599 (4.38), $661 \mathrm{~nm}$ (5.01). Analysis: calcd for $\mathrm{C}_{32} \mathrm{H}_{16} \mathrm{~N}_{8} \mathrm{FeClC}$, 63.65; H, 2.67; N, 18.56; Found: C, 63.94; H, 2.86; N, 18.83 .

\section{Phthalocyaninatocopper(II) $\mathrm{C}_{32} \mathrm{H}_{16} \mathrm{~N}_{8} \mathrm{Cu}(11 \mathrm{a})^{8 \mathrm{c}}$}

IR (nujol): 3108, 3078, 2988, 1648, 1578, 1525, 1484, 1442, 1289, 1119, 1092, 960, 804, 728, 766, $729 \mathrm{~cm}^{-1}$. UV-Vis (DMF): $\lambda_{\max }(\log$ e) 344 (4.93), 603 (4.48), $669 \mathrm{~nm}$ (5.08). Analysis: calcd for $\mathrm{C}_{32} \mathrm{H}_{16} \mathrm{~N}_{8} \mathrm{Cu}$ C, 66.72; H, 2.80; N, 19.45; Found: C, 66.95; H, 2.98; N, 19.72. MS (ESI): $\mathrm{m} / \mathrm{z}$ calcd for $\mathrm{C}_{32} \mathrm{H}_{16} \mathrm{~N}_{8} \mathrm{Cu}$ : 576.07; found: $577.18\left[\mathrm{M}+\mathrm{H}^{+}\right]$.

\section{[2(3),9(10),16(17),23(24)-Tetrakis(nitro)phthalocyaninato]zinc(II) $\mathrm{C}_{32} \mathrm{H}_{12} \mathrm{~N}_{12} \mathrm{O}_{8} \mathrm{Zn}$ (7i) ${ }^{8 \mathrm{c}}$}

IR (nujol): 3098, 3042, 2982, 1652, 1608, 1520, 1342, 1136, 1084, 1042, 848, $726 \mathrm{~cm}^{-1}$. UV-Vis (DMF): $\lambda_{\max }(\log$ e) 345 (4.36), 647 (4.12), 684 (4.38), $703 \mathrm{~nm}$ (5.30). Analysis: calcd for $\mathrm{C}_{32} \mathrm{H}_{12} \mathrm{~N}_{12} \mathrm{O}_{8} \mathrm{Zn} \mathrm{C}, 50.71 ; \mathrm{H}, 1.60 ; \mathrm{N}, 22.18$; Found: C, 50.92; H, 1.42; N, 22.54. 


\section{Synthesis of metallophthalocyanines from metal free phthalocyanines; Method C}

A mixture of metal free phthalocyanine (5a, 200mg) and corresponding metal salts (1 equivalents) were stirred at $100^{\circ} \mathrm{C}$ with functional ionic liquid 2c (1 equivalent) for the appropriate time. The progress of the reaction was monitored by TLC and UV-Visible spectroscopic analysis. When reaction was completed, the mixture was cooled to room temperature, and distilled water $(50 \mathrm{~mL})$ was added to dissolve the functional ionic liquid. The blue-green solid mass was filtered and the aqueous filtrate was evaporated using reduced pressure to recover the pure ionic liquid for further use. The solid mass was further washed thoroughly with $\mathrm{H}_{2} \mathrm{O}-\mathrm{MeOH}(1: 1,100 \mathrm{~mL})$ to remove the colorless impurities and metallophthalocyanines are obtained in pure form in excellent yield.

\section{References}

1. Domanska, U. Thermochimica Acta. 2006, 448, 19-30.

2. Shen, Y.; Kennedy, D. F.; Greaves, T. L.; Weerawardena, A.; Mulder, R. J.; Kirby, N.; Song, G.; Drummond, C. J. Phys. Chem. Chem. Phys., 2012,14, 7981-7992

3. (a) Bicak, N. J. Mol. Liq. 2005, 116, 15-18; (b) Iranpoor, N.; Firouzabadi, H.; Ahmadi, Y. Eur. J. Org. Chem. 2012, 305-311.

4. Burrell, A. K.; Sesto, R. E. D.; Baker, S. N.; Mccleskey, T. M.; Baker, G. A. Green Chem. 2007, 9, 449-454.

5. Peng, Y.; Li, G.; Li, J.; Yu, S. Tetrahedron Lett. 2009, 50, 4286-4288.

6. Chakraborti, A. K.; Roy, S. R. J. Am. Chem. Soc. 2009, 131, 6902-6903.

7. Zhang, S.; Qi, X.; Ma, X.; Lu, L.; Deng, Y. J. Phys. Chem. B. 2010, 114, 3912-3920.

8. (a) Chauhan, S. M. S.; Srinivas, K. A.; Srivastava, P. K.; Sahoo, B. J. Porphyrins Phthalocyanines. 2003, 7, 548-550; (b) Chauhan, S. M. S.; Agarwal, S.; Kumari, P. Synth. Commun. 2007, 37, 2917-2925; (c) Chauhan, S. M. S.; Kumari, P.; Agarwal, S. Synthesis 2007, 23, 3713-3721. 
9. Shabbani, A.; Moghaddam, R. M.; Maleki, A.; Rezayan, A. H. Dyes and Pigments 2007, $74,279-282$.

10. Luzyanin, K. V.; Kukushkin, V. Y.; Kopylovich, M. N.; Nazarov, A. A.; Galanski, M.; Pombeiro, A. J. L. Adv. Synth. Catal. 2008, 350, 135-142.

11. Kobayashi, N.; Ogata, H.; Nonaka, N.; Luk'yanets, E. A. Chem. Eur. J. 2003, 9, 51235134.

12. Young, J. G.; Onyebuagu, W. J. Org. Chem.1990, 55, 2155-2159.

13. Kumar, T. M. M.; Achar, B. N. J. Phys. Chem. Solids. 2006, 67, 2282-2288. 


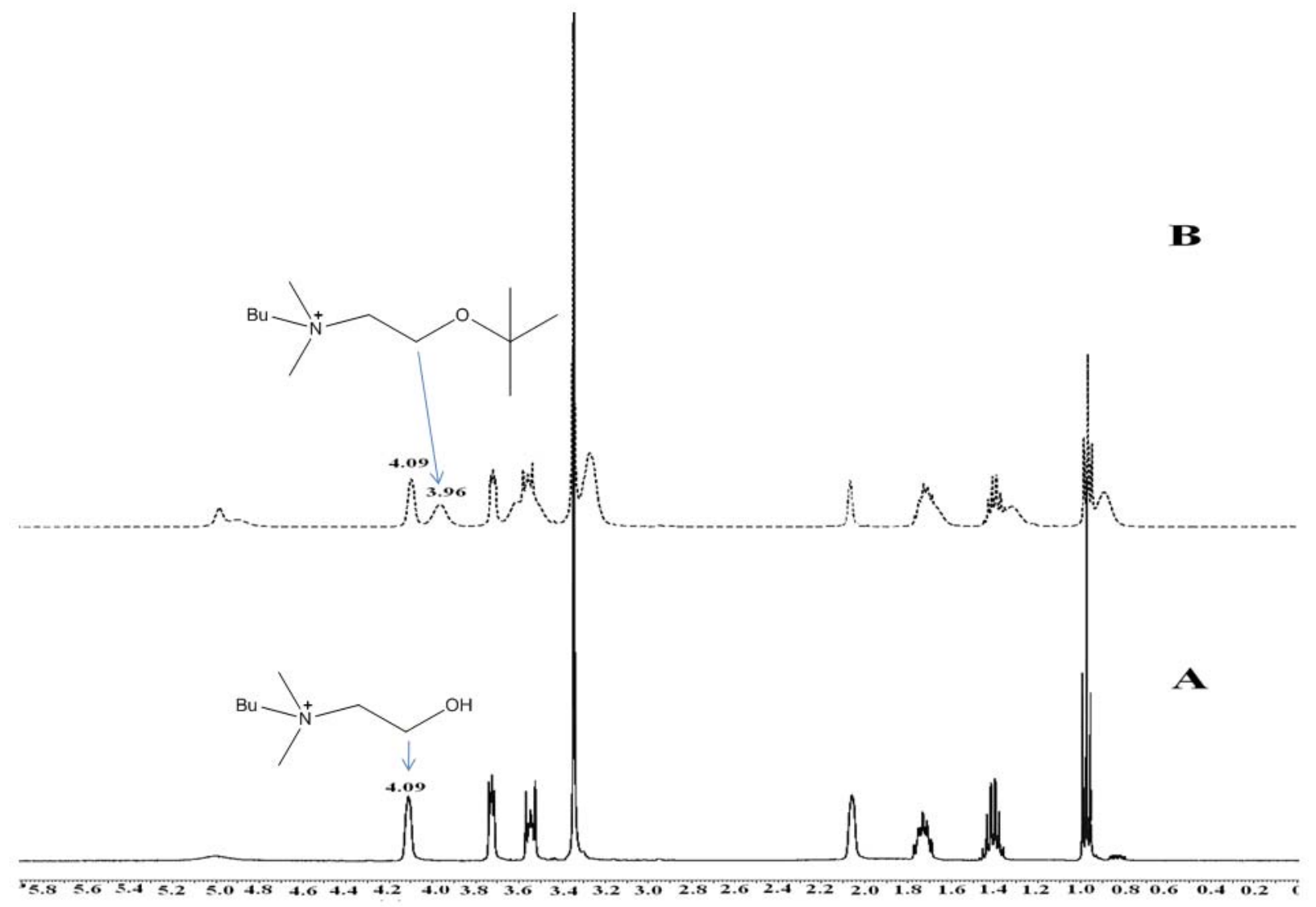

Figure S1: (A) ${ }^{1} \mathrm{H}$ NMR spectrum of pure ionic liquid 2c in $\mathrm{CDCl}_{3}$; (B) ${ }^{1} \mathrm{H} \mathrm{NMR}$ spectrum of reaction mixture of ionic liquid 2c with t-butyl chloride in $\mathrm{CDCl}_{3}$. 


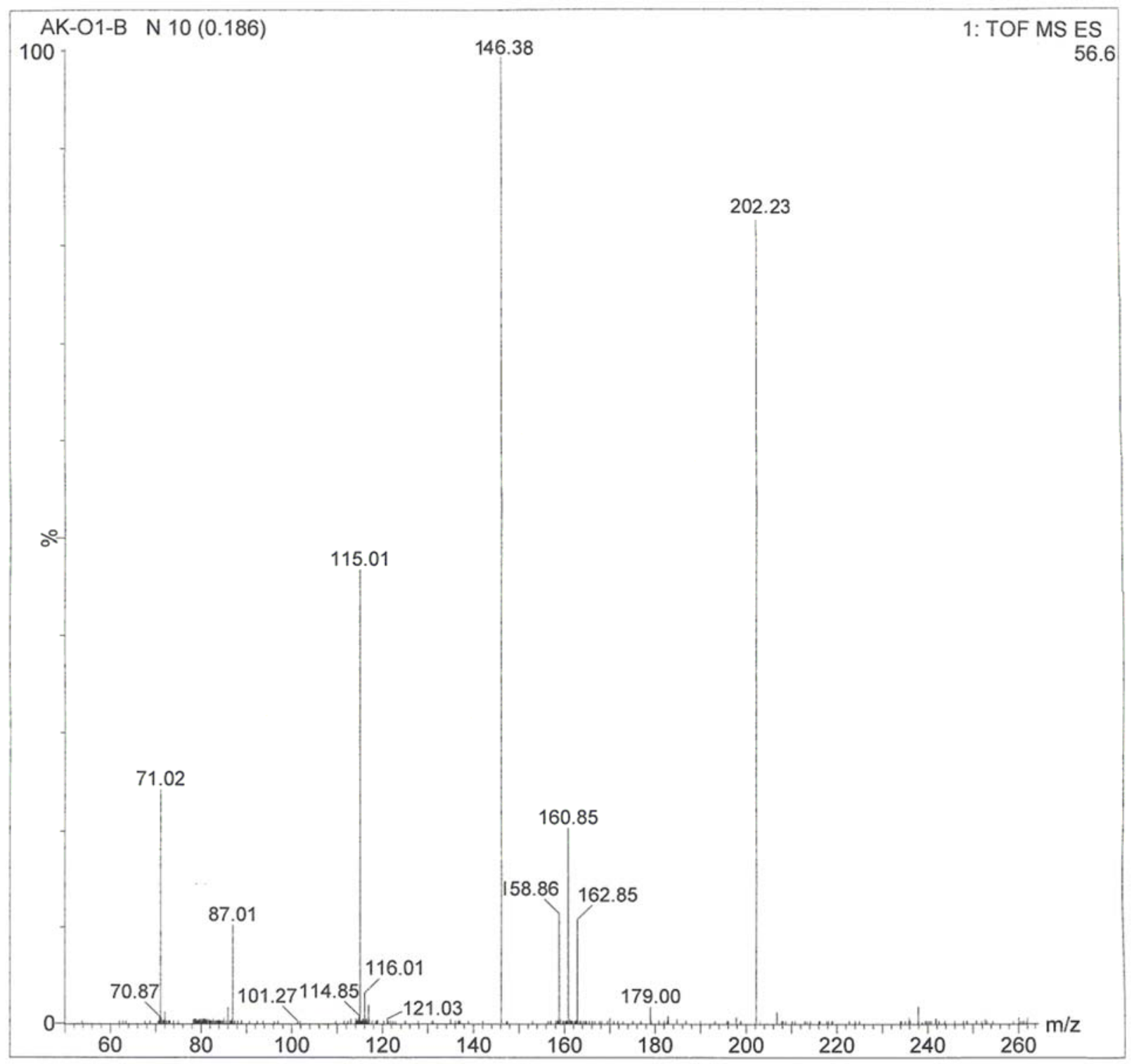

Figure S2: ESI-MS of reaction mixture of ionic liquid 2c with t-butyl chloride. 